\title{
Interrelasi Antara Negara Hukum, Demokrasi Dan Hukum Administrasi Negara Melalui Campur Tangan Pemerintah Dalam Hukum Ketenagakerjaan
}

\section{Oleh : \\ MILA KARMILA ADI}

\begin{abstract}
Labor Law in Indonesia is one of specific law that has a main goal to protect the workers in front of entrepreneur's power. This article uses normative method in analyzing the interrelation of Constitutional State, Democracy, and Administrative Law, in Labor Law aspect, especially on the government intervention to the worker and entrepreneur relationship. Based on a democratic and constitutional state, the government shall protect and respect human rights of citizen by using juridical instruments. Thus, in fulfilling his duties in labor aspect, the government has a responsibility in order to reach a social justice between the parties in working relationship. Also, the government has a responsibility to interfere the working relationship between parties by some limitations and regulations of the Indonesian Democratic and Constitutional State based on Pancasila.
\end{abstract}

